\title{
The Effectiveness of Using Digital Game towards Students' Academic Achievement in Small and Large Classes: A Comparative Research
}

\author{
Saprudin Saprudin, Liliasari Liliasari and Andhy Setiawan \\ Universitas Pendidikan Indonesia \\ Bandung-West Java, Indonesia
}

\author{
Ary Setijadi Prihatmanto \\ Institut Teknologi Bandung \\ Bandung-West Java, Indonesia
}

\begin{abstract}
The reduced engagement of students in large classes is one concern that may have an impact on the low level of students' academic achievement. The use of a digital game is one proven teaching media that increase students' engagement in learning. This research seeks to compare the effectiveness of using digital games towards students' academic achievement in small and large classes. This quasiexperimental research uses a pretest-posttest nonequivalent multiple group design involving 58 pre-service physics teachers in two classes, namely small class and large class. Both classes use the same digital game application to study the nature of light. Data were collected through a paper and pencil test consisting of multiple-choice questions. The result showed that the use of a digital game could increase students' academic achievement. The students' game score achievement and the increase in academic achievement were positively correlated. The use of a digital game in large classes can significantly increase students' academic achievement compared to small classes.
\end{abstract}

Keywords: Digital Game; Class sizes; Engagement; Academic Achievement.

\section{Introduction}

As the development of information and communication technology (ICT) is accelerating, public awareness regarding the importance of education is increasing. Due to higher awareness, more people strive for education. Meanwhile, increasing the number of teachers and facilities is difficult to be done by educational institutions. Therefore, one effect that cannot be avoided is an increase in class sizes. Class sizes are related to the number of students who 
take a course in a particular learning environment (Wadesango, et al., 2016). In some literature, class sizes represent student-teacher ratios (Mahlo, 2015).

Previous research has reported a negative relationship between class sizes and student learning outcomes (Raimondo et al., 1990). Students who study in small classes show higher performance in reading scores compared to large classes, but this does not occur in math scores (Iacovou, 2002). In small classes there is more individual attention, students can be more engaged in discussions, this can help students to learn and remember information more effectively (Butler et al., 2001; McKeachie, 2002; Yoder \& Hochevar,2005; Blatchford et al., 2007; Pollock et al., 2011). Therefore, small classes have a positive impact on student performance (Arias \& Walker, 2004).

In contrast to those findings, other research states that there is no significant difference in students' academic achievement in small classes and large classes (Owoeye \& Yara, 2011). Class size has no relationship with academic achievement (Hoxby, 2000; Stecher et al., 2003; Milesi \& Gamoran, 2006; Mahlo, 2015). Research has shown that the effect of class size towards academic achievement is due to the aspect of students' engagement (Finn et al., 2003). The aspect becomes essential in supporting the effectiveness of the learning process.

One strategy that ensures the increase of students' engagement in a meaningful way is through digital games. The impact of game design without being integrated with educational theory will not be optimal. The integration of educational theories or the implementation of strategies, models, and learning methods has been carried out to optimize the use of digital games in learning science, especially physics, such as cooperative/ collaborative strategies (Echeverría et al., 2011; Echeverría et al., 2012a; Sung \& Hwang, 2013; Tsai et al., 2015; Chen et al., 2015; Van eaton et al., 2015), 5E learning cycle (Dorji et al., 2015), atomic intrinsic integration approach (Echeverría et al., 2012b), hands-on integration with video games (Anderson \& Barnett, 2013), assessment (Shute et al., 2013; Hwang et al., 2014; Kim \& Shute, 2015; Tsai et al., 2015), strengthening reflection/ meta-cognition (Verpoorten et al., 2014), cognitive-affective interaction model (Hsiao et al., 2014), conceptual physics (Sengupta et al., 2015), self-explanation (Adams \& Clark, 2014; Killingsworth et al., 2015), locus of control (Yang et al., 2016) and concept map (Hwang et al., 2013; Sun et al., 2015).

Previous research results indicate that the use of digital games in learning physics concepts can increase students' engagement in the learning process (Shute, et al., 2013; Hamari, et al., 2016), joyful learning (Kim \& Shute, 2015), motivation (Sung \& Hwang, 2013; Hwang, et al., 2013; Hwang et al., 2014; Chen, et al., 2015; Killingsworth, et al., 2015), students' perception (Hwang, et al., 2013; Chen, et al., 2015; Hwang, et al., 2014; Tsai, et al., 2015; Hamari, et al., 2016), attitude towards learning (Sung \& Hwang, 2013), flow experiences (Tsai, et al., 2016), efficacy (Sung \& Hwang, 2013; Sun, et al., 2015), facilitating concept changes (Sengupta, 2015), concept elaboration (Sun, et al., 2015), divergent thinking (Hsiao, et al., 2014), problem-solving (Hwang, et al., 2014; Chen, et al., 2016), that impacted on the increase of students' academic achievement (Echeverría, et al., 2012b; Anderson \& Barnett, 2013; Shute, et al., 2013; Sung \& Hwang, 2013; Hwang, et al., 2013; Verpoorten, et al., 2014; Hwang, et al., 2014; Adams \& Clark, 2014; Dorji, et al., 2015; Tsai, et al., 2015; Chen, et al., 2015; 
Killingsworth, et al., 2015; Yang, et al., 2016; Tsai, et al., 2016), creativity and manual skills (Hsiao, et al., 2014); as well as improving students' awareness (Dorji, et al., 2015). Besides that, the use of digital games can also decrease the cognitive load (Hwang et al., 2013).

Waves and optics course is one of the courses in which most pre-service physics teachers (PPTs) still experience difficulties learning. Preliminary research indicates the PPTs' low academic achievement in this course (Saprudin, et al., 2017; Saprudin et al., 2019a; Saprudin et al., 2019b). In general, the concept labels in this course contain abstract concept attributes. This is supported by many research that shows that many students experience difficulties in conceptualizing abstract concepts (McDermott \& Redish, 1999; Wittmann et al., 1999; Wosilait et al., 1999; Galili \& Hazan, 2000). The abstract concepts make students less motivated to be engaged in the learning process, which in turn has an impact on the low level of students' academic achievement (Saprudin et al., 2017; Saprudin et al., 2019a; Saprudin et al., 2019b).

In general, research related to the use of digital games in learning physics is more focused on the impact of the use of digital games itself on learning outcomes. Research related to the comparison of the effectiveness of the use of digital games in small classes and large classes in increasing students' academic achievement is still rarely found. The empirical evidence related to the successful use of digital games can serve as a reference that digital games can be an alternative solution in solving the decrease of students' engagement or participation, especially in learning with large class settings. Besides, the use of digital games is closely related to competition. The more participants in a game, the atmosphere created becomes more joyful and competitive. Each participant will be motivated to work with the challenges given, as well as possible. In the context of learning, a big question arises regarding how is the comparison of the effectiveness of the use of digital games to students' academic achievement in large and small classes. Therefore, the research question raised in this research is: "is the use of the digital game more effective in increasing students' academic achievement in large classes compared to small classes?'.

This article describes an investigation related to the comparison of the effectiveness of the use of a digital game in increasing students' academic achievement in a small class and large class settings. The results of this research are expected to be useful in planning physics learning more effectively, especially for learning in large class settings.

\section{Theoretical Framework}

\subsection{Digital Game}

Game is as an activity that is immersive, voluntary, and fun, to achieve challenging goals based on agreed rules (Kinzie \& Joseph, 2008). In the context of e-learning, a game is defined as an online environment that involves competitive activities with challenges to achieve goals and has a particular set of rules, constraints, and specific contexts (Clark \& Mayer, 2011). Educational games can be viewed as a competitive rule-based activity involving one or more players to achieve goals at a superior level (winning) either concerning the 
previous level of performance/ single-player game or concerning the level of performance of other players, success in the activity requires use of subject matter in some way (Rieber, 2005).

In other literature, the game is a system in which players engage in an intellectual challenge, defined by rules, interactivity, and feedback that result in a quantifiable outcome, often eliciting an emotional reaction (Kapp et al., 2014). Digital games can also be seen as a teaching media (Anderson \& Barnett, 2013; Hwang et al., 2013; Verpoorten et al., 2014; Sun et al., 2015; Shute et al., 2013; Killingsworth et al., 2015; Van Eaton et al., 2015; Van der Graaf et al., 2016), assessment tool (Shute et al., 2013; Hwang et al., 2014; Kim \& Shute, 2015; Tsai et al., 2015) and as a learning environment (Hsiao et al., 2014; Adams \& Clark, 2014).

\subsection{Digital Game in Physics Learning}

In various researches, there has been much empirical evidence related to the successful use of digital games in learning physics concepts. Physics content, in this case, is not only implied, specifically in physics subjects, but also in science subjects with physics content in its learning material.

Table 1: Studies Related to the Use of Digital Games in Learning Physics

\begin{tabular}{|c|c|c|}
\hline $\begin{array}{c}\text { Target Level of } \\
\text { Education }\end{array}$ & Authors & Physics Content \\
\hline Kindergarten & Van der Graaf, et al., 2016 & $\begin{array}{l}\text { The Slides, the Seesaw, and the } \\
\text { Pendulum }\end{array}$ \\
\hline \multirow[t]{2}{*}{ Elementary School } & Hsiao et al., 2014 & Electricity \\
\hline & Hwang et al., 2014 & Global Warming Effects \\
\hline \multirow[t]{8}{*}{ Junior High School } & Anderson \& Barnett, 2013 & Electrostatics, electromagnetism \\
\hline & Shute et al., 2013 & $\begin{array}{l}\text { Newton's Playground (Balance, mass } \\
\text { and conservation, transfer of } \\
\text { momentum, gravity, potential energy, } \\
\text { and kinetic energy) }\end{array}$ \\
\hline & Verpoorten et al., 2014 & Optics \\
\hline & Adams \& Clark, 2014 & Newton's Laws \\
\hline & Sun, et al., 2015 & Pendulum concept, Circular motion \\
\hline & Chen et al., 2015 & $\begin{array}{l}\text { Force } \\
\end{array}$ \\
\hline & Sengupta et al., 2015 & Newton Mechanics \\
\hline & Tsai et al., 2015 & Energy \\
\hline \multirow[t]{5}{*}{ Senior High School } & White, 1984 & Newton's Law of Motion \\
\hline & Echeverria et al., 2011 & Electrostatics \\
\hline & Dorji et al., 2015 & $\begin{array}{l}\text { Electrical Energy (electricity use and } \\
\text { energy savings) }\end{array}$ \\
\hline & Hamari et al., 2016 & Optics \\
\hline & Chen et al., 2016 & Geology \\
\hline \multirow{2}{*}{ Higher Education } & Yang et al., 2016 & Energy \\
\hline & Tsai et al., 2016 & Electromagnetics \\
\hline
\end{tabular}

The success of digital games in facilitating learning is inseparable from the role of the game elements themselves. The game elements are based on "The Elemental Tetrad of Games" framework (Schell, 2008), classified into four categories, namely mechanics, stories, aesthetics, and technology. The game mechanics describes the procedures and rules of the game, determining how the player can achieve the goals of the game. The mechanics consist of the elements 
of space, objects, attributes and states, actions, rules, skills, chance. The story illustrates the sequence of events that develops during gameplay. Aesthetics describes how the game looks (graphic design, color) and sounds (music, sound effects). Technology defines the material and interactions that allow games to be played, and includes elements such as input and display devices. The technology used in a game will provide the ability to do something and the prohibition to do something else (Schell, 2008). In other literature, Becker (2008) states that game elements consist of artificial intelligence, attract mode, back story, boss challenges, cut scenes, game rules, heads up display, level of detail or point of view, levels, non-playable character, narrative, outcome, perspective, sandbox mode, story mode, time; actual and game-time, trailers, tutorial mode, and valorization.

\section{Method}

\subsection{Research Methods and Design}

The method used in this research is a quasi-experiment method with pretestposttest nonequivalent multiple group design (Wiersma \& Jurs, 2009).

Table 2: Research Design

\begin{tabular}{|c|c|c|c|}
\hline Group & $\begin{array}{c}\text { Pretest } \\
\text { (dependent variable) }\end{array}$ & Experimental Variable & $\begin{array}{c}\text { Posttest } \\
\text { (dependent variable) }\end{array}$ \\
\hline $\mathrm{G}_{1}$ & $\mathrm{O}_{1}$ & $\begin{array}{c}\text { The use of a digital game } \\
\left.\text { in the small class ( } \mathrm{n}_{1}=18\right)\end{array}$ & $\mathrm{O}_{2}$ \\
\hline $\mathrm{G}_{2}$ & $\mathrm{O}_{3}$ & $\begin{array}{c}\text { The use of a digital game } \\
\text { in the large class }\left(\mathrm{n}_{2}=40\right)\end{array}$ & $\mathrm{O}_{4}$ \\
\hline
\end{tabular}

\subsection{Participant}

This research involved 58 PPTs enrolled in the course of waves and optics, specifically PPTs who studied the nature of light. Participants were divided into two groups without randomization, namely experimental group 1 (18 PPTs, $\mathrm{M}=$ $5, \mathrm{~F}=13$, average age $=19$ years 8 months) and experimental group 2 (40 PPTs, $\mathrm{M}=10, \mathrm{~F}=30$, average age $=20$ years 2 months). The experimental group 1 referred to as the small class, and the experimental group 2 as the large class (Blatchford \& Mortimore, 1994; Scheck et al., 1994; Arias \& Walker, 2004; Blatchford et al., 2007). Both classes used the same digital game application to learn the nature of light and sound waves.

\subsection{Procedure}

The digital game used in this research was a puzzle focused on exploring the similarities and differences between light and sound waves. Conventional learning generally delivers the learning material through lectures. However, in this study, students are encouraged to explore the material through the digital game applications in an online mode. 


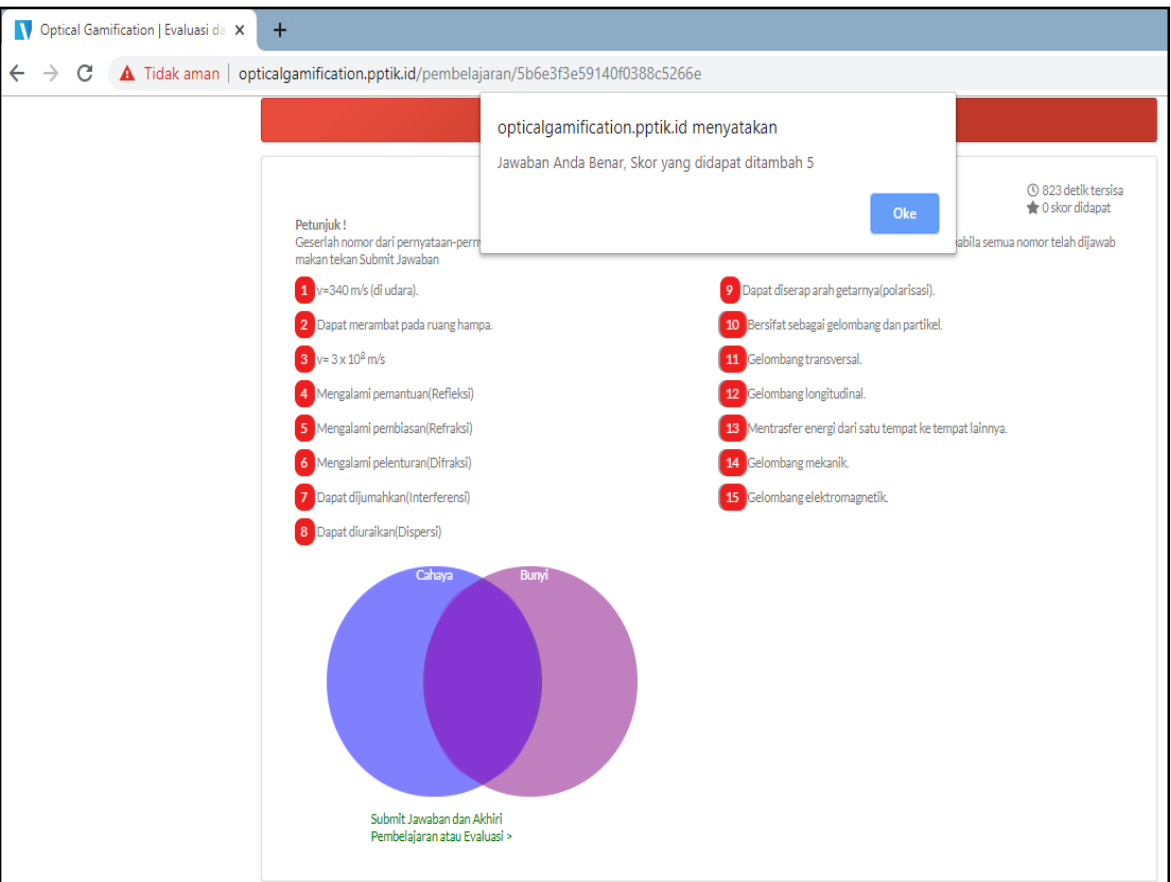

(a)

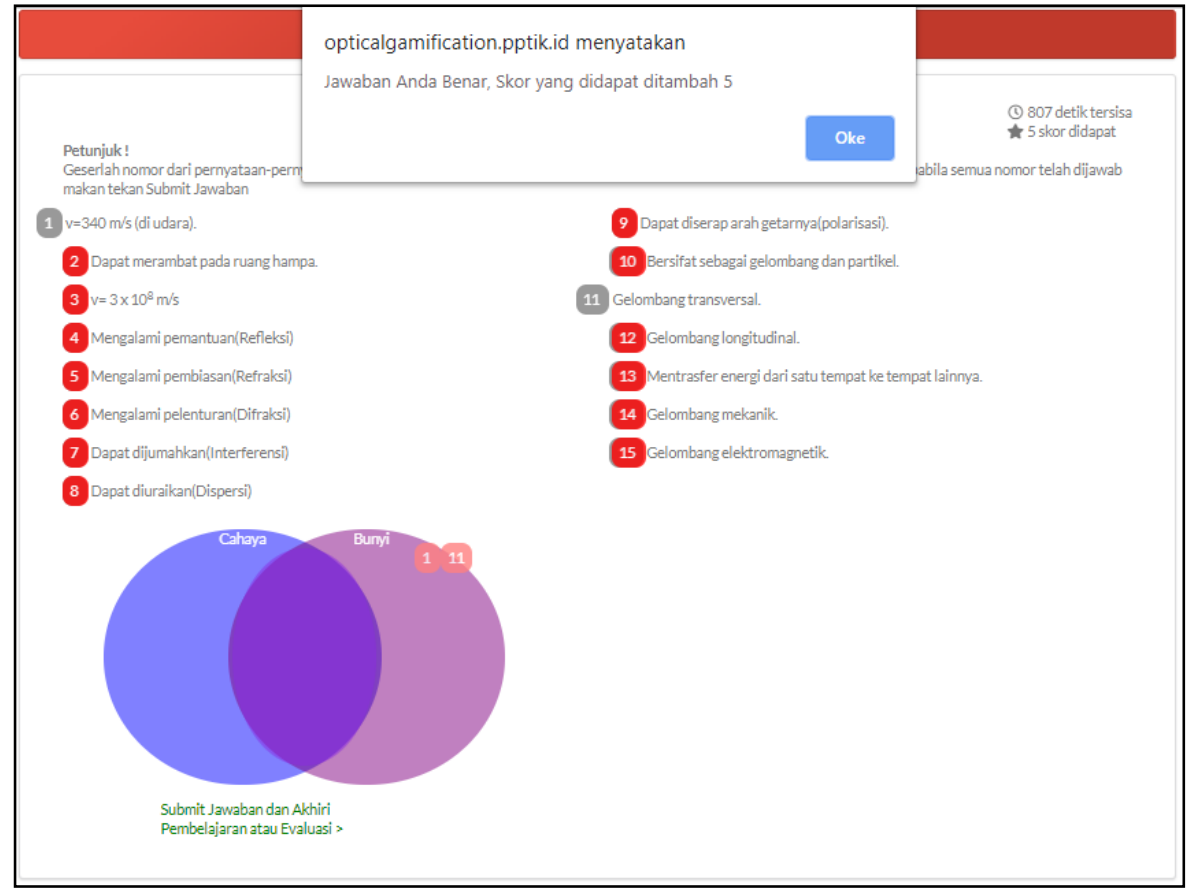

(b)

Figure 1 (a), (b): The Digital Game Application's Interface

Students can see a list of characteristics of light and sound waves. They have to put the characteristics into a Venn diagram. The system will automatically provide feedback on each answer. If they answered correctly, their scores would automatically increase. This digital game application is presented online in http://opticalgamification.pptik.id/. However, each student is required to have a username and password to enter the system. 
The learning process, both in small and large classes, was carried out with the same learning settings, namely learning using the digital game application. The students took a pretest before the learning process started. Students completed the task in one week by exploring the nature of light through the online game application. After participating in the learning process, students took a post-test.

\subsection{Data Gathering and Data Analysis Technique}

Data related to students' academic achievement were collected through a paper and pencil test consisting of multiple-choice questions. Pretest and posttest are set up separately outside the game application system. The increase in students' academic achievement was determined by calculating normalized gain (Hake, 1998).

$$
\langle g\rangle=\frac{\%\left\langle\mathrm{~S}_{\mathrm{f}}\right\rangle-\%\left\langle\mathrm{~S}_{\mathrm{i}}\right\rangle}{100-\% \mathrm{~S}_{\mathrm{i}}}
$$

Where $S_{\mathrm{f}}$ and $S_{i}$ are the final (post) and initial (pre) class averages. Normalized gain is interpreted to be in the high category if $(\langle g\rangle) \geq 0.70$, the medium category if $0.7>(\langle g\rangle) \geq 0.30$, and the low category if $(\langle g\rangle)<0.30$. Inferential statistical analysis was done to compare the effectiveness of using digital games in the small and the large class in increasing students' academic achievement.

\section{Results and Discussion}

\subsection{Students' Game Score Achievement}

The game score achievement for the students in small and large classes are shown in Figure 2 and 3.

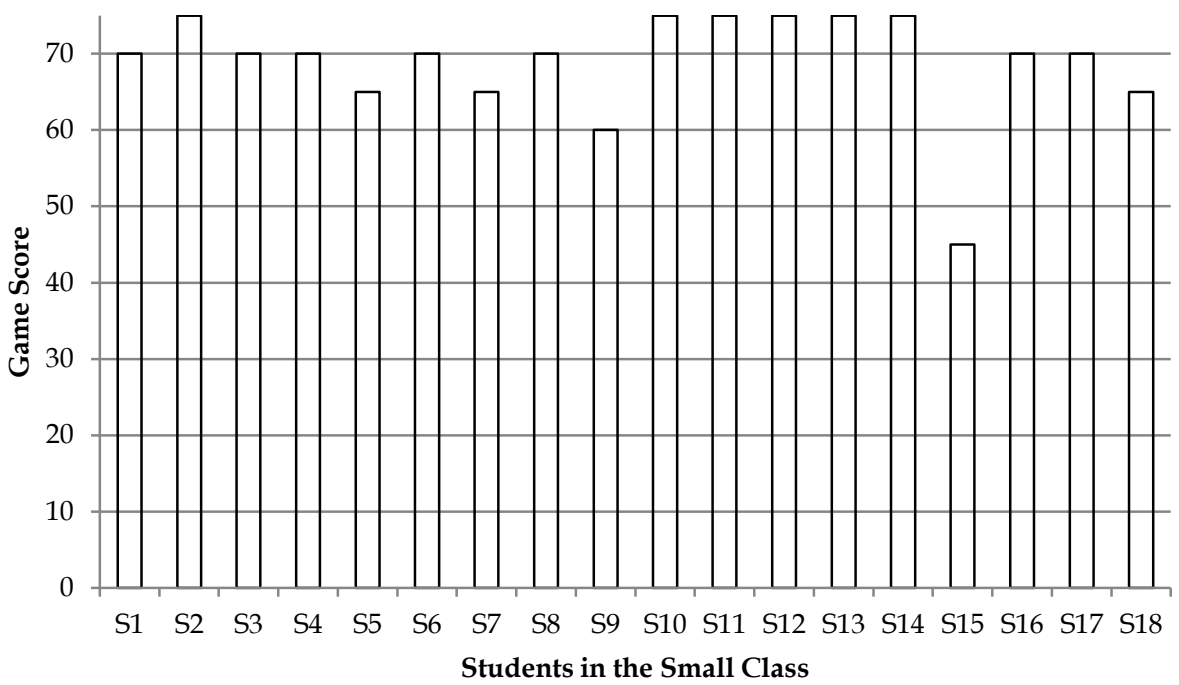

Figure 2: Game Score Achievement for Students in the Small Class 


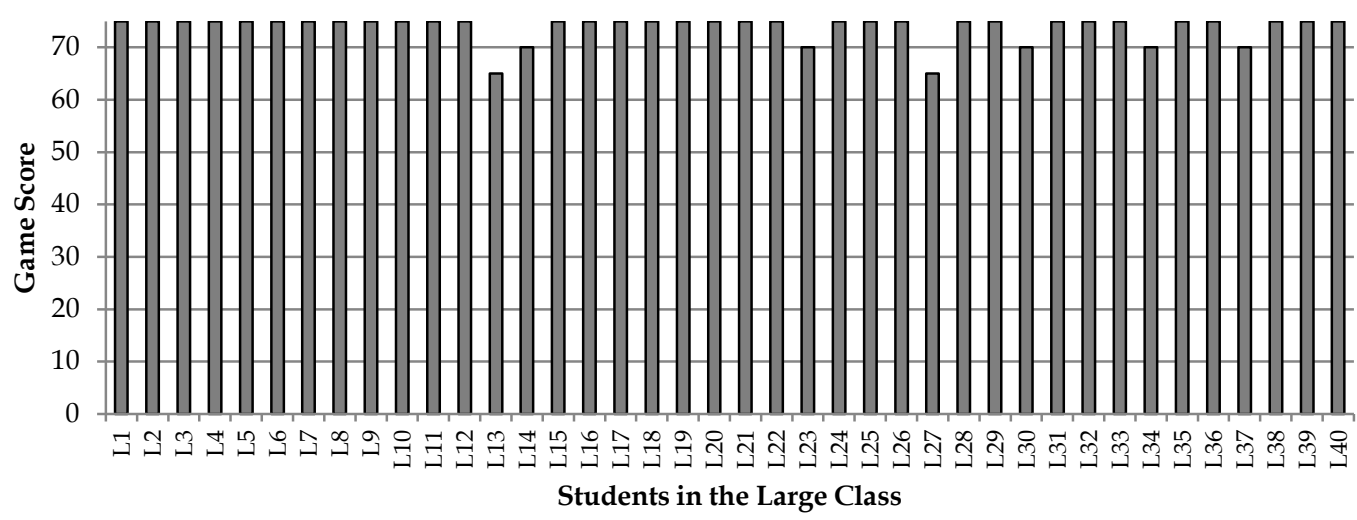

Figure 3: Game Score Achievement for Students in the Large Class

Figure 2 and 3 shows that $82.5 \%$ of students in the large class could reach the maximum game score, while only $15.0 \%$ for students in the small class. More students in the large class could reach the maximum game score $(X \max =75)$ compared to the students in the small class. The use of a digital game in the large class can create a more significant competitive atmosphere compared to the small class. High competition motivates students to be able to do the tasks provided in the game as well as possible.

\subsection{The Profile of Students'Academic Achievement}

The data of pretest and posttest scores of students' academic achievement in both classes are analyzed and processed using SPSS 16.0 software and are shown in Table 3.

Table 3: The Processed Results Students' Pretest and Posttest Scores in the small and large classes

\begin{tabular}{|l|c|c|c|c|}
\hline \multirow{2}{*}{ Statistical test parameters } & \multicolumn{2}{c|}{ Small Class } & \multicolumn{2}{c|}{ Large Class } \\
\cline { 2 - 5 } & Pretest & Posttest & Pretest & Posttest \\
\hline Mean & 35.19 & 72.22 & 48.33 & 90.00 \\
\hline Std. Deviation & 26.75 & 30.78 & 23.81 & 17.21 \\
\hline $\begin{array}{l}\text { Normality test } \\
\text { One-Sample Kolmogorov-Smirnov Test }\end{array}$ & Sig. 0.383 & Sig. 0.172 & Sig. 0.000 & Sig. 0.000 \\
\hline & \multicolumn{2}{|c|}{ Pretest } & \multicolumn{2}{c|}{ Posttest } \\
\hline Test of Homogeneity of Variances & \multicolumn{2}{|c|}{ Sig. 0.978} & \multicolumn{2}{c|}{ Sig. 0.005} \\
\hline $\begin{array}{l}\text { Hypothesis Testing } \\
\text { (Mann-Whitney; U test) }\end{array}$ & \multicolumn{2}{|c|}{ Sig. 0.067} & \multicolumn{2}{c|}{ Sig. 0.019} \\
\hline
\end{tabular}

Table 3 shows that, overall, students' academic achievement has increased after participating in the learning process by using a digital game, both in the small and the large class. The result of the normality test by using One-Sample Kolmogorov-Smirnov Test shows that the data of the pretest and posttest scores of students in the small class were normally distributed. As for students in the large class, the pretest and posttest scores were not normally distributed. The results of nonparametric statistical tests using the Mann-Whitney test found no significant differences in the results of the pretest between students who took part in learning by using a digital game in the small class and the large class. This means that both classes have relatively similar initial abilities before participating in the learning process. Meanwhile, the Mann-Whitney test results on posttest 
scores found that there were significant differences between students who took part in the learning process by using a digital game in the small and the large class. To see a comparison of the effectiveness of the increase in students' academic achievement between the small and the large class, the normalized gain scores in both classes were compared.

\subsection{Comparison of the Effectiveness of Using Digital Game in the Small and the Large Class}

The percentage of pretest, posttest, and normalized gain $\langle g\rangle$ scores for the students' academic achievement test results is shown in Figure 4.

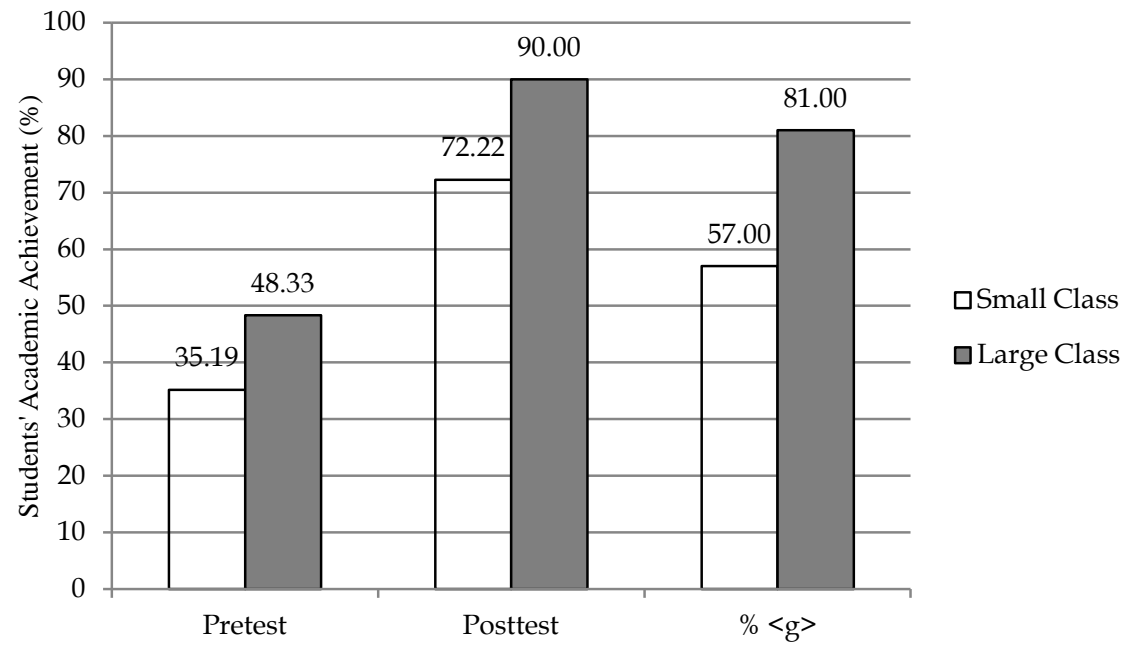

Figure 4: Students' Academic Achievementin the Small and Large Class

Figure 4 shows that students' academic achievement has increased after participating in the learning process by using a digital game both in small and large classes. This means that the use of a digital game can increase students' academic achievement. The calculation results of normalized gain $\langle g\rangle$ showed that the increase in students' academic achievement in the small class was categorized as medium $(\langle g\rangle=0.57)$, while those in the large class was categorized as high $(\langle g\rangle=0.81)$. The results of data processing $\langle g\rangle$ statistically are shown in Table 4 .

Table 4: Statistical Processing Results for Data $\langle g\rangle$ in the Small Class and the Large Class

\begin{tabular}{|l|c|c|}
\hline \multicolumn{1}{|c|}{ Statistical test parameters } & Small Class & Large Class \\
\hline Mean & 0.57 & 0.81 \\
\hline Std. Deviation & 0.57 & 0.39 \\
\hline $\begin{array}{l}\text { Normality Test } \\
\text { One-Sample Kolmogorov-Smirnov Test }\end{array}$ & Sig. 0.118 & Sig. 0.000 \\
\hline Test of Homogeneity of Variances & \multicolumn{2}{|c|}{ Sig. 0.033} \\
\hline $\begin{array}{l}\text { Hypothesis Testing } \\
\text { (Mann-Whitney; U test) }\end{array}$ & \multicolumn{2}{|c|}{ Sig. 0.041} \\
\hline
\end{tabular}

Based on the results of statistical tests, data $\langle g\rangle$ in the small class were normally distributed, while the data in the large class were not normally distributed. Mann-Whitney test result on normalized gain data $\langle g\rangle$ shows that the use of a 
digital game in the large class significantly increases students' academic achievement compared to the use of a digital game in the small class.

Further analysis result was done by analyzing the relationship between game scores $(\mathrm{X})$ with an increase in students' academic achievement $(\mathrm{Y})$ in the large class. Statistical test results related to the regression equation, correlation coefficient, and coefficient of determination are shown in Table 5.

Table 5: Regression Equation, Correlation Coefficient $(r)$, and Coefficient of Determination $\left(R^{2}\right)$

\begin{tabular}{|c|c|c|c|}
\hline Regression equation & $\boldsymbol{r}$ & Category & $\boldsymbol{R}^{\mathbf{2}}$ \\
\hline $\mathrm{Y}=70,682+4,098 \mathrm{X}$ & 0,601 & Strong & 0,362 \\
\hline
\end{tabular}

Table 5 shows that there is a positive correlation between students' game scores and students' academic achievement. Through this equation, it can be estimated that the higher game score obtained by students, the higher the academic achievement will be.

\subsection{Discussion}

The result of the research shows that the use of the digital game in physics learning was more effective for students in the large class compared to the students in the small class. The engagement of students in small and large classes is one crucial aspect to support academic achievement (Finn et al., 2003). The use of a digital game can increase student engagement in learning in a meaningful way (Shute et al., 2013; Hamari et al., 2016). This shows that the use of a digital game can be an alternative solution to problems related to a reduction in student engagement in the learning process, especially in large classes.

The successful use of a digital game in physics learning cannot be separated from the role of each game element. Through the existence of competition and challenge elements, students deal with problems that must be resolved based on specific rules. The existence of point and leaderboard elements can potentially increase students' motivation to find alternative solutions. The results showed that the digital game was successful in increasing students' motivation to learn (Sung \& Hwang, 2013; Hwang et al., 2013; Hwang et al., 2014; Chen et al., 2015; Killingsworth et al., 2015; Cam \& Tran, 2017).

The use of digital game not only can be used in learning concrete concepts, but also for abstract concepts. The use of a digital game has the potential to be able to engage students in complex physics phenomena, facilitate observations and interactions with phenomena in 3D and phenomena that are mentally difficult to transform 2D objects into 3D objects, e.g., electricity and magnetism material (Anderson \& Barnett, 2013; Dorji et al., 2015).

An increase in students' motivation and engagement in learning by using the digital game is proven to be able to increase students' academic achievement. This research shows that the increase in students' academic achievement in the large class is significantly higher than students in the small class. The results of this research are expected to be a reference that class size is no longer a barrier to being able to present active learning in the future. Students' engagement in the learning process, especially in large classes, can be ensured and can even be 
increased by using ICT-based learning media, one of which is through a digital game.

\section{Conclusion}

There is a positive correlation between students' game scores with an increase in students' academic achievement. The use of a digital game can be one alternative solution in overcoming problems related to the reduction of student engagement in the learning process, especially in large classes. The use of a digital game in large classes can significantly increase the students' academic achievement compared to students in small classes.

\section{Acknowledgment}

The researcher expresses appreciation towards LPDP, BUDI-DN as the primary sponsor in this research. The researcher also expresses his appreciation to the students and lecturers who participated in this research.

\section{References}

Adams, D. M., \& Clark, D. B. (2014). Integrating self-explanation functionality into a complex game environment: Keeping gaming in motion. Computers $\mathcal{E}$ Education, 73, 149-159. https://doi.org/10.1016/j.compedu.2014.01.002

Anderson, J. L., \& Barnett, M. (2013). Learning physics with digital game simulations in middle school science. Journal of science education and technology, 22(6), 914-926. https://doi.org/10.1007/s10956-013-9438-8

Arias, J. J., \& Walker, D. M. (2004). Additional evidence on the relationship between class size and student performance. The Journal of Economic Education, 35(4), 311-329. https://doi.org/10.3200/JECE.35.4.311-329

Becker, K. (2008). Video Game Pedagogy: Good Game = Good Pedagogy (Chapter 5, Games: Purpose and Potential in Education, editor by Christopher Thomas Miller). Springer Science+Business Media, LLC2008

Blatchford, P., \& Mortimore, P. (1994). The issue of class size for young children in schools: what can we learn from research?. Oxford Review of Education, 20(4), 411428. https:// doi.org/10.1080/0305498940200402

Blatchford, P., Russell, A., Bassett, P., Brown, P., \& Martin, C. (2007). The effect of class size on the teaching of pupils aged 7-11 years. School effectiveness and school improvement, 18(2), 147-172. https:/ / doi.org/10.1080/09243450601058675

Butler, A., Phillmann, K. B., \& Smart, L. (2001). Active learning within a lecture: Assessing the impact of short, in-class writing exercises. Teaching of Psychology, 28(4), 257-259. https://doi.org/10.1207/S15328023TOP2804_04

Cam, L., \& Tran, T. T. M. (2017). An Evaluation of Using Games in Teaching English Grammar for First-Year English-Majored Students at Dong Nai Technology University. International Journal of Learning, Teaching and Educational Research, 16(7), 55-71.

Chen, C. H., Wang, K. C., \& Lin, Y. H. (2015). The comparison of solitary and collaborative modes of game-based learning on students' science learning and motivation. Journal of Educational Technology \& Society, 18(2), 237-248.

Chen, C. L. D., Yeh, T. K., \& Chang, C. Y. (2016). The Effects of Game-Based Learning and Anticipation of a Test on the Learning Outcomes of 10th Grade Geology Students. Eurasia Journal of Mathematics, Science \& Technology Education, 12(5). https://doi.org/10.12973/eurasia.2016.1519a 
Clark, R. C., \& Mayer, R. E. (2011). E-Learning and the Science of Instruction. San Fransisco: Pfeiffer.

Dorji, U., Panjaburee, P., \& Srisawasdi, N. (2015). A learning cycle approach to developing educational computer games for improving students' learning and awareness in electric energy consumption and conservation. Journal of Educational Technology \& Society, 18(1), 91-105.

Echeverría, A., García-Campo, C., Nussbaum, M., Gil, F., Villalta, M., Améstica, M., \& Echeverría, S. (2011). A framework for the design and integration of collaborative classroom games. Computers \& Education, 57(1), 1127-1136. https:// doi.org/10.1016/j.compedu.2010.12.010

Echeverría, A., Améstica, M., Gil, F., Nussbaum, M., Barrios, E., \& Leclerc, S. (2012a). Exploring different technological platforms for supporting co-located collaborative games in the classroom. Computers in Human Behavior, 28(4), 11701177. https://doi.org/10.1016/j.chb.2012.01.027

Echeverría, A., Barrios, E., Nussbaum, M., Améstica, M., \& Leclerc, S. (2012b). The atomic intrinsic integration approach: A structured methodology for the design of games for the conceptual understanding of physics. Computers $\mathcal{E}$ Education, 59(2), 806-816. https://doi.org/10.1016/j.compedu.2012.03.025

Finn, J. D., Pannozzo, G. M., \& Achilles, C. M. (2003). The "why's" of class size: Student behavior in small classes. Review of Educational Research, 73(3), 321-368. https://doi.org/10.3102\%2F00346543073003321

Galili, I., \& Hazan, A. (2000). Learners' knowledge in optics: interpretation, structure, and analysis. International Journal of Science Education, 22(1), 57-88. https:// doi.org/10.1080/095006900290000

Hake, R. R. (1998). Interactive-engagement versus traditional methods: A six-thousandstudent survey of mechanics tests' data for introductory physics courses. American Journal of Physics, 66(1), 64-74. https://doi.org/10.1119/1.18809

Hamari, J., Shernoff, D. J., Rowe, E., Coller, B., Asbell-Clarke, J., \& Edwards, T. (2016). Challenging games help students learn: An empirical study on engagement, flow, and immersion in game-based learning. Computers in human behavior, 54, 170-179. https:// doi.org/10.1016/j.chb.2015.07.045

Hoxby, C. M. (2000). The effects of class size on student achievement: New evidence from population variation. The Quarterly Journal of Economics, 115(4), 1239-1285. https://doi.org/10.1162/003355300555060

Hsiao, H. S., Chang, C. S., Lin, C. Y., \& Hu, P. M. (2014). Development of children's creativity and manual skills within a digital game-based learning environment. Journal of Computer Assisted Learning, 30(4), 377-395. https://doi.org/10.1111/jcal.12057

Hwang, G. J., Hung, C. M., \& Chen, N. S. (2014). Improving learning achievements, motivations, and problem-solving skills through a peer assessment-based game development approach. Educational Technology Research and Development, 62(2), 129-145. https://doi.org/10.1007/s11423-013-9320-7

Hwang, G. J., Yang, L. H., \& Wang, S. Y. (2013). A concept map-embedded educational computer game for improving students' learning performance in natural science courses. Computers $\&$ Education, 69, 121-130. https:// doi.org/10.1016/j.compedu.2013.07.008

Iacovou, M. (2002). Class size in the early years: Is smaller better?. Education Economics, 10(3), 261-290. https:/ / doi.org/10.1080/09645290210127499

Kapp, K. M., Blair, L., \& Mesch, R. (2014). The Gamification of Learning and Instruction Fieldbook: Ideas into Practice, John Wiley \& Sons. 
Killingsworth, S. S., Clark, D. B., \& Adams, D. M. (2015). Self-Explanation and Explanatory Feedback in Games: Individual Differences, Gameplay, and Learning. International Journal of Education in Mathematics, Science and Technology, 3(3), 162-186.

Kim, Y. J., \& Shute, V. J. (2015). The interplay of game elements with psychometric qualities, learning, and enjoyment in game-based assessment. Computers $\mathcal{E}$ Education, 87, 340-356. https://doi.org/10.1016/j.compedu.2015.07.009

Kinzie, M. B., \& Joseph, D. R. (2008). Gender differences in a game activity preferences of middle school children: implications for educational game design. Educational Technology Research and Development, 56(5-6), 643-663. https://doi.org/10.1007/s11423-007-9076-z

Mahlo, D. (2015). A Comparative Study of Class Size and Academic Achievement of Pupils in Boarding and Non-Boarding Schools. International Journal of Educational Sciences, 11(2), 128-136. https:/ / doi.org/10.1080/09751122.2015.11890383

McDermott, L. C., \& Redish, E. F. (1999). Resource letter: PER-1: Physics education research. American journal of physics, 67(9), 755-767. https://doi.org/10.1119/1.19122

McKeachie, W. J. (2002). McKeachie's teaching tips: Strategies, research, and theory for college and university teachers (11th Ed.). Boston, MA: Houghton-Mifflin. https://doi.org/10.1353/rhe.2003.0066

Milesi, C., \& Gamoran, A. (2006). Effects of class size and instruction on kindergarten achievement. Educational Evaluation and Policy Analysis, 28(4), 287-313. https://doi.org/10.3102\%2F01623737028004287

Owoeye, J. S., \& Yara, P. O. (2011). School location and academic achievement of secondary school in Ekiti State, Nigeria. Asian social science, 7(5), 170-175. https://doi.org/10.5539/ass.v7n5p170

Pollock, P. H., Hamann, K., \& Wilson, B. M. (2011). Learning through discussions: Comparing the benefits of small-group and large-class settings. Journal of Political Science $\quad$ Education, 7(1), 48-64. https://doi.org/10.1080/15512169.2011.539913

Raimondo, H. J., Esposito, L., \& Gershenberg, I. (1990). Introductory class size and student performance in intermediate theory courses. The Journal of Economic Education, 21(4), 369-382. http:/ / dx.doi.org/10.1080/00220485.1990.10844682

Rieber, L. P. (2005). Multimedia Learning in Games, Simulations, and Microworlds (chapter 33). In R. E. Mayer, The Cambridge Handbook of Multimedia Learning New York, United States of America: Cambridge University Press, pp. 549-568. https://doi.org/10.1017/CBO9780511816819.034

Saprudin, S., Liliasari, L., \& Prihatmanto, A. S. (2017, September). Pre-Service Physics Teachers' Concept Mastery and the Challenges of Game Development on Physics Learning. In Journal of Physics: Conference Series (Vol. 895, No. 1, pp. 012109). IOP Publishing. https:/ / doi.org/10.1088/1742-6596/895/1/012109

Saprudin, S., Liliasari, S., Prihatmanto, A. S., \& Setiawan, A. (2019a, February). Profile of pre-service physics teachers' creative thinking skills on wave and optics course. In Journal of Physics: Conference Series (Vol. 1157, No. 3, pp. 032030). IOP Publishing. https:/ / doi.org/10.1088/1742-6596/1157/3/032030

Saprudin, S., Liliasari, S., Prihatmanto, A. S., \& Setiawan, A. (2019b, February). Preservice physics teachers' thinking styles and its relationship with critical thinking skills on learning interference and diffraction. In Journal of Physics: Conference Series (Vol. 1157, No. 3, p. 032029). IOP Publishing. https://doi.org/10.1088/1742-6596/1157/3/032029 
Scheck, C. L., Kinicki, A. J., \& Webster, J. L. (1994). The effect of class size on student performance: Development and assessment of a process model. Journal of Education for Business, 70(2), 104-111. https://doi.org/10.1080/08832323.1994.10117734

Schell, J. (2008). The Art of Game Design: A Book of Lenses. Burlington, MA: Morgan Kaufmann Publishers

Sengupta, P., Krinks, K. D., \& Clark, D. B. (2015). Learning to deflect: Conceptual change in physics during digital gameplay. Journal of the Learning Sciences, 24(4), 638674. October - December 2015. https:// doi.org/10.1080/10508406.2015.1082912

Shute, V. J., Ventura, M., \& Kim, Y. J. (2013). Assessment and learning of qualitative physics in newton's playground. The Journal of Educational Research, 106(6), 423430. https:// doi.org/10.1080/00220671.2013.832970

Stecher, B. M., McCaffrey, D. F., \& Bugliari, D. (2003). Relationship between Exposure to Class Size Reductionand Student Achievementin California. Education policy analysis archives, 11, 40. https://doi.org/10.14507/epaa.v11n40.2003

Sun, C. T., Ye, S. H., \& Wang, Y. J. (2015). Effects of commercial video games on the cognitive elaboration of physical concepts. Computers $\mathcal{E}$ Education, 88, 169-181. https://doi.org/10.1016/j.compedu.2015.05.002

Sung, H. Y., \& Hwang, G. J. (2013). A collaborative game-based learning approach to improving students' learning performance in science courses. Computers $\mathcal{E}$ Education, 63, 43-51. https:// doi.org/10.1016/j.compedu.2012.11.019

Tsai, F. H., Tsai, C. C., \& Lin, K. Y. (2015). The evaluation of different gaming modes and feedback types on game-based formative assessment in an online learning environment. Computers $\mathcal{E} \quad$ Education, 81, 259-269. https:// doi.org/10.1016/j.compedu.2014.10.013

Tsai, M. J., Huang, L. J., Hou, H. T., Hsu, C. Y., \& Chiou, G. L. (2016). Visual behavior, flow, and achievement in game-based learning. Computers $\mathcal{E}$ Education, 98, 115129. https://doi.org/10.1016/j.compedu.2016.03.011

Van der Graaf, J., Segers, E., \& Verhoeven, L. (2016). Discovering the laws of physics with a serious game in kindergarten. Computers \& Education, 101, 168-178. https:// doi.org/10.1016/j.compedu.2016.06.006

Van Eaton, G., Clark, D. B., \& Smith, B. E. (2015). Patterns of Physics Reasoning in Faceto-Face and Online Forum Collaboration around a Digital Game. International Journal of Education in Mathematics, Science and Technology, 3(1), 1-13.

Verpoorten, D., Castaigne, J. L., Westera, W., \& Specht, M. (2014). A quest for metalearning gains in a physics serious game. Education and Information Technologies, 19(2), 361-374. https:/ / doi.org/10.1007/s10639-012-9219-7

Wadesango, N., Hove, J., \& Kurebwa, M. (2016). Effects of large class size on effective curriculum implementation. International Journal of Educational Sciences, 12(2), 173-183. https:// doi.org/10.1080/09751122.2016.11890424

White, B. Y. (1984). Designing computer games to help physics students understand Newton's laws of motion. Cognition and instruction, 1(1), 69-108. https://doi.org/10.1207/s1532690xci0101_4

Wiersma, W., \& Jurs, S. G. (2009). Research Methods in Education an introduction Ninth Edition. United States of America: Pearson Education, Inc.

Wittmann, M. C., Steinberg, R. N., \& Redish, E. F. (1999). Making sense of how students make sense of mechanical waves. The physics teacher, 37(1), 15-21. https://doi.org/10.1119/1.880142

Wosilait, K., Heron, P. R., Shaffer, P. S., \& McDermott, L. C. (1999). Addressing student difficulties in applying a wave model to the interference and diffraction of light. American Journal of Physics, 67(S1), S5-S15. https:// doi.org/10.1119/1.19083 
Yang, J. C., Lin, Y. L., \& Liu, Y. C. (2016). Effects of locus of control on behavioral intention and learning performance of energy knowledge in game-based learning. Environmental Education Research 23(6),

886-899. https://doi.org/10.1080/13504622.2016.1214865

Yoder, J. D., \& Hochevar, C. M. (2005). Encouraging active learning can improve students' performance on examinations. Teaching of Psychology, 32(2), 91-95. 